\title{
KAJI EKSPERIMENTAL PREDIKSI KETEBALAN NITRIDASI PADA BAJA SKD 61 MENGGUNAKAN METODE GELOMBANG ULTRASONIK
}

\author{
Albert Christian Wanandi ${ }^{1}$, Hadi Sutanto ${ }^{2}$, Roziq Himawan ${ }^{3}$ \\ ${ }^{1}$ Mahasiswa Program Studi Teknik Mesin, Universitas Katolik Indonesia Atma Jaya \\ ${ }^{2}$ Profesor Program Studi Teknik Mesin, Universitas Katolik Indonesia Atma Jaya \\ ${ }^{3}$ Pusat Teknologi dan Keselamatan Reaktor Nuklir - BATAN
}

\begin{abstract}
ABSTRAK
KAJI EKSPERIMENTAL PREDIKSI KETEBALAN NITRIDASI PADA BAJA SKD 61 MENGGUNAKAN METODE GELOMBANG ULTRASONIK. Lapisan yang terbentuk pada permukaan material seperti lapisan karburasi pada bagian dalam pipa menyebabkan permukaan pipa tersebut mengalami pengerasan, dan apabila terjadi retak, retak tersebut dapat memicu kebocoran. Pencegahan terjadinya kerusakan tersebut memerlukan dilakukannya pengukuran ketebalan lapisan, dengan metode tidak merusak. Pada penelitian ini akan dikembangkan metode pengukuran lapisan tipis pada material dengan metode ultrasonik. Lapisan tipis dibuat dengan proses nitridasi yang mewakili lapisan akibat karburasi pada pipa. Spesimen terbuat dari material baja SKD61. Proses nitridasi menghasilkan ketebalan lapisan berbeda-beda yaitu $59 \mu \mathrm{m}, 102 \mu \mathrm{m}$, dan $160 \mu \mathrm{m}$. Metode ultrasonik yang digunakan adalah metode Ultrasonic Water Immersion menggunakan satu Probe dan defocusing. Besaran yang dijadikan acuan adalah cepat rambat gelombang permukaan Rayleigh. Hasil eksperimen menunjukkan bahwa metode defocused tidak memperlihatkan pengaruh ketebalan lapisan nitridasi pada cepat rambat gelombang Rayleigh, sementara metode satu probe memperlihatkan pengaruh ketebalan lapisan nitridasi terhadap cepat rambat gelombang Rayleigh.
\end{abstract}

Kata kunci: lapisan nitridasi, ultrasonic water immersion, gelombang permukaan, defocusing, metode satu probe

\section{ABSTRACT}

EXPERIMENTAL STUDY PREDICTION OF NITRIDATION THICKNESS IN SKD 61 STEEL USING ULTRASONIC WAVES METHOD. Thin layer on material surface such as carburizing layer on internal surface of pipe causes surface hardening If a crack occurs in this layer, it triggers a leak on the pipe Prevention the leak needs a measurement of layer thickness non-destructively. The aim of this study is to develop measurement method of thin layer on material using ultrasonic method. Thin layers were made by nitridization process to simulate carburizing in boiler pipe. Specimens were made from SKD61 steel. Nitridizing processes resulted various thickness, that are $59 \mu \mathrm{m}$, $102 \mu \mathrm{m}$, dan $160 \mu \mathrm{m}$. Ultrasonic water immersion method was used in this study by using one probe method and focusing method. The parameter to determine the thickness was propagation velocity of Rayleigh surface wave. Experimental results show that focusing method doesn't show the effects of nitridizing layer's thickness on propagation velocity of Rayleigh surface wave, while the one probe method shows the effects of nitridizing layer's thickness on propagation velocity of Rayleigh surface wave.

Keywords: nitridizing layer, ultrasonic water Immersion, surface wave, defocusing, one probe method 


\section{PENDAHULUAN}

Pipa yang berfungsi mengalirkan uap panas akan menimbulkan proses karburisasi pada bagian dalam pipa, sehingga seiring dengan waktu pemakaiannya, akan terbentuk lapisan karbon. Lapisan ini sifatnya keras dan kaku, sehingga jika terjadi inisiasi retak di bagian permukaan dalam pipa, maka retak tersebut akan mengalami perambatan yang sangat cepat yang dapat mengakibatkan kebocoran ataupun patah. Kondisi ini dapat terjadi pada pipa sistem pendingin sekunder Pembangkit Tenaga Listrik atau pipa boiler pada Pembangkit Listrik Tenaga Uap. Jika pipa mengalami kebocoran, maka akan menyebabkan pemadaman pembangkit.

Risiko kerusakan pada pipa akibat proses karburisasi dapat dikurangi dengan memonitor ketebalan lapisan karbon yang terbentuk pada pipa. Agar monitoring dapat dilakukan tanpa merusak pipa, maka harus dilakukan secara tak merusak. Pada monitoring ini, metode yang mudah dan tanpa menimbulkan paparan radiasi adalah metode ultrasonik. Oleh karena itu, tujuan penelitian ini adalah melakukan prediksi ketebalan lapisan permukaan material menggunakan metode ultrasonic. Pada penelitian sebelumnya, metode ultrasonik berhasil digunakan untuk memonitor proses degradasi akibat fatik ${ }^{[1]}$ dan mendeteksi cacat blister pada elemen bahan bakar nuklir ${ }^{[2]}$. Kedua metode ultrasonik tersebut memanfaatkan jenis gelombang longitudinal untuk melakukan pengujian. Pada monitoring lapisan karbon ini, penggunaan gelombang longitudinal tidak dapat dilakukan karena lapisan yang terbentuk biasanya sangat tipis, yaitu pada orde mikrometer. Sehingga lebih tepat menggunakan gelombang permukaan jenis gelombang Rayleigh. Sebagaimana namanya, gelombang ini merambat di sepanjang permukaan material. Sehingga, karena cepat rambat gelombang ultrasonik dipengaruhi oleh karakteristik material, maka adanya lapisan pada permukaan material akan mengakibatkan perubahan cepat rambat gelombang ultrasonik.

Berbagai penelitian yang berhubungan dengan pemanfaatan gelombang ultrasonik jenis gelombang permukaan telah banyak dilakukan. H.M. Shodja et al ${ }^{[3]}$ memanfaatkan gelombang permukaan tipe Love untuk mendeteksi lapisan tipis. Y. Shen [4] melakukan analisis gelombang permukaan pada ikatan tiga lapisan. Pengukuranpengukuran lapisan tipis maupun lapisan di bawah permukaan berhasil dilakukan dengan metode disperse gelombang permukaan, kombinasi gelombang permukaan, dan metode non -linier ${ }^{[5-8]}$. Sementara itu tipe gelombang Rayleigh berhasil digunakan untuk melakukan perhitungan tegangan dan pengukuran lapisan pada silinder ${ }^{[9,10]}$.

Pada penelitian ini diperlukan ketebalan lapisan yang sudah diketahui. Karena keterbatasan spesimen, maka lapisan permukaan diganti dengan lapisan hasil proses nitridasi. Sehingga, spesimen dibuat dengan melakukan nitridasi pada material logam, dengan ketebalan yang berbeda-beda. Dalam rangka memperoleh metode pengukuran yang efektif dan efisien, digunakan tiga metode untuk membangkitkan gelombang permukaan 
Rayleigh. Dari penelitian ini akan diperoleh hubungan antara cepat rambat gelombang Rayleigh dengan tebal lapisan permukaan.

\section{TEORI}

\section{Gelombang Rayleigh}

Gelombang Rayleigh atau Rayleigh waves adalah gelombang yang merambat pada permukaan material dengan arah pergerakan atom yang berbentuk ellips (surface Rayleigh). Gelombang Rayleigh memiliki penetrasi ke dalam material hanya sampai kedalaman satu panjang gelombang. Sebagaimana diperlihatkan pada Gambar 1, intensitas gelombang Rayleigh berkurang hingga di bawah 10\% pada kedalaman lebih dari satu panjang gelombang (sumbu mendatar dilambangkan dengan $\mathrm{z} / \lambda \mathrm{R})$. Berdasarkan hal ini, maka kemampuan deteksi gelombang Rayleigh sangat dipengaruhi oleh panjang gelombangnya. Semakin besar panjang gelombang, maka akan mampu mendeteksi sampai dalam, namun sebaliknya, sensitivitas di dekat permukaan (sub-surface) akan berkurang.

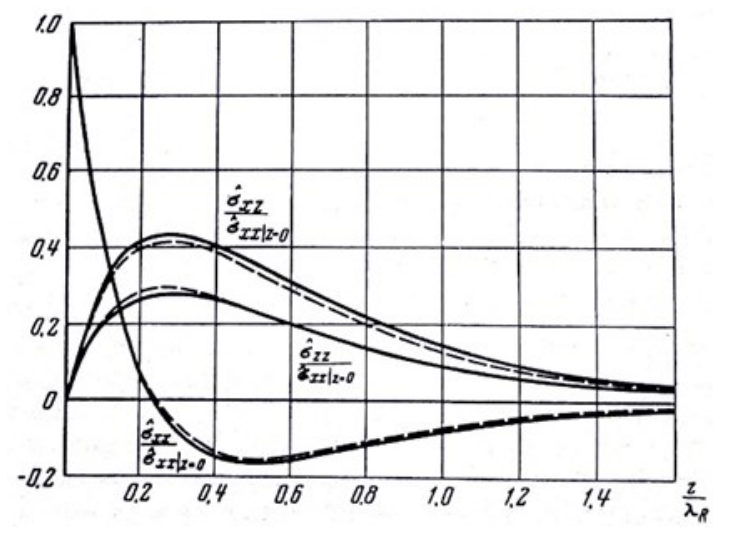

Gambar 1. Intensitas Rayleigh waves ${ }^{[11]}$

\section{Pembangkitan Gelombang Rayleigh}

Dalam perambatan gelombang, apabila terjadi perubahan media perambatan, maka pada bidang batas (material interface), sebagian gelombang akan dipantulkan dan sebagian lagi diteruskan. Intensitas gelombang yang dipantulkan dan diteruskan, tergantung pada nilai acoustic impedance yang disimbulkan dengan Z. Acoustic impedance merupakan perkalian antara nilai cepat rambat gelombang dengan massa jenis benda. Hal ini terjadi apabila gelombang datang membentuk sudut $90^{\circ}$ terhadap bidang batas. Apabila gelombang datang membentuk sudut tertentu terhadap bidang datar, maka gelombang yang diteruskan akan mengalami pembiasan. Besarnya nilai sudut datang, sudut pantul dan sudut bias mengikuti hukum Snellius ${ }^{[12]}$. Berdasarkan hukum Snellius, semakin besar sudut datang, semakin besar pula sudut pantul dan sudut biasnya. Ketika sudut bias mencapai $90^{\circ}$ atau sejajar dengan bidang batas, maka gelombang tersebut merambat pada bidang batas. Apabila gelombang datang dari media cair menuju ke media padat, maka gelombang akan merambat pada permukaan benda padat yang berbatasan dengan benda cair. Gelombang ini disebut gelombang Rayleigh atau gelombang permukaan. Sudut datang gelombang yang memberikan sudut bias sebesar $90^{\circ}$ disebut sudut kritis. Hukum Snellius yang mengatur hubungan antara sudut datang, sudut pantul, dan sudut bias ini dinyatakan dengan persamaan berikut ini.

$$
\frac{\sin \theta_{1}}{v_{1}}=\frac{\sin \theta_{2}}{v_{2}}
$$


Jadi, gelombang Rayleigh dapat dibangkitkan mengacu pada hukum Snellius dengan cara membentuk sudut datang gelombang ultrasonik sampai terjadi gelombang yang dihasilkan sudut bias senilai $90^{\circ}$.

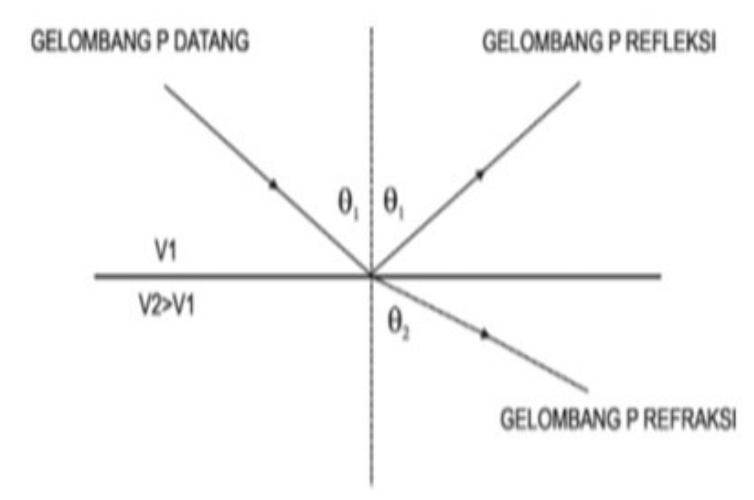

Gambar 2. Hukum Snellius ${ }^{[12]}$

\section{METODOLOGI}

Pada penelitian ini, lapisan karbon disimulasikan menjadi lapisan hasil nitridasi. Spesimen objek penelitian terbuat dari material baja SKD 61. Pembentukan lapisan dilakukan melalui proses nitridasi dengan parameter temperutur. Adapun temperature nitridasi yang yang digunakan adalah $5300^{\circ} \mathrm{C}, 550^{\circ} \mathrm{C}$, dan 570 ${ }^{\circ} \mathrm{C}$. Adapun ketebalan lapisan hasil nitridasi diperlihatkan pada Tabel 1.

Tabel 1. Ketebalan hasil Nitridasi.

\begin{tabular}{|l|c|c|c|}
\hline Temp. & $530{ }^{\circ} \mathrm{C}$ & $550{ }^{\circ} \mathrm{C}$ & $570{ }^{\circ} \mathrm{C}$ \\
\hline Ketebalan & $59 \mu \mathrm{m}$ & $102 \mu \mathrm{m}$ & $160 \mu \mathrm{m}$ \\
\hline
\end{tabular}

Prediksi tebal lapisan nitridasi dilakukan dengan memanfaatkan Leaky Rayleigh wave (gelombang permukaan yang bocor) yang merambat pada permukaan benda uji. Besaran yang menjadi parameter pengukuran adalah cepat rambat gelombang dengan cara mengukur waktu yang diperlukan untuk merambat pada jarak tertentu. Pembangkitan gelombang Rayleigh dilakukan dengan dua cara sebagai berikut.

\section{A. Metode Defocused}

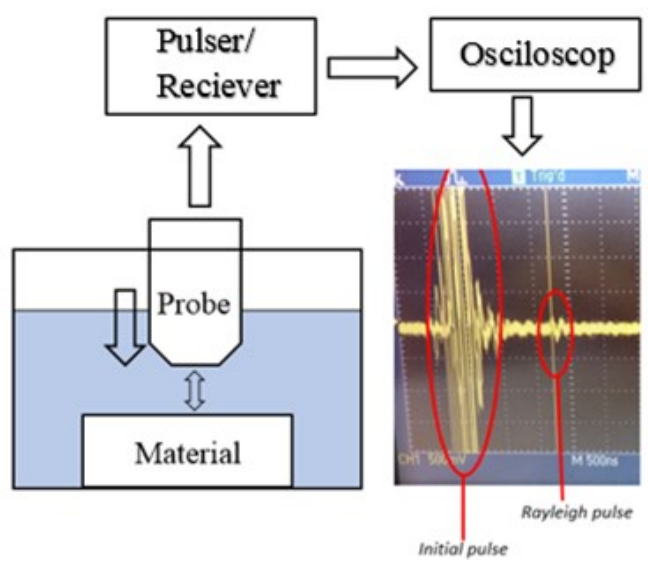

Gambar 3. Skema Uji Metode Defocused

Gambar 3 memperlihatkan skema uji metode Defocused. Pada metode ini, sistem pengujian terdiri dari Ultrasonic Pulser Receiver, Probe dan Osciloscope. Ultrasonic Pulser Receiver berfungsi untuk membangkitkan sinyal gelombang ultrasonik dan menerima sinyal pantul. Osciloscope berfungsi menayangkan sinyal elektronik gelombang ultrasonik dan probe berfungsi untuk mengubah energi elektronik menjadi energi mekanik yang dipancarkan ke spesimen dan sebaliknya. Probe yang digunakan memiliki frekuensi 10 MHz dan tipe fokus dengan jarak fokus 25,4 $\mathrm{mm}$. Maksud dari metode defocused ini adalah, pada saat pengukuran waktu perambatan, jarak antara probe dan spesimen bukan 25,4 mm, melainkan diubah-ubah kurang dari 25,4 $\mathrm{mm}$.

Penentuan cepat rambat gelombang Rayleigh dilakukan sebagai berikut. Gambar 4 
memperlihatkan skema terjadinya gelombang permukaan Rayleigh. Pada saat posisi jarak $\mathrm{x}$ sesuai dengan jarak focus probe yaitu 25,4 mm, maka titik $\mathrm{O}$ berada pada permukaan spesimen. Pada posisi ini, gelombang yang terpancar dari titik manapun di bagian busur AED, dipantulkan kembali ke probe sesuai hukum Snellius. Namun, apabila probe diturunkan, yang berarti jarak x semakin pendek, maka titik O seolaholah berada di dalam spesimen. Pada posisi ini, maka berdasarkan model berkas (Ray model) hanya ada dua komponen gelombang yang kembali ke probe, yaitu komponen EO'E dan ABO'CD. Komponen kedua ini merupakan gelombang permukaan Rayleigh yang terjadi berdasarkan hukum Snellius.

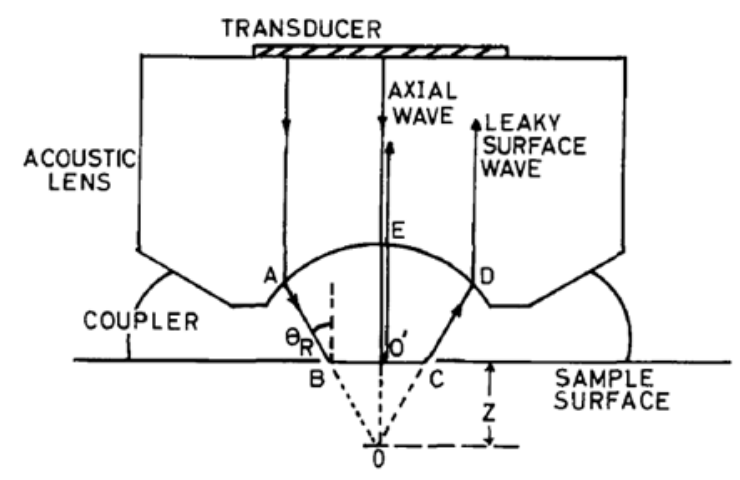

Gambar 4. Skema penentuan cepat rambat ${ }^{[13]}$

Untuk menentukan cepat rambat gelombang permukaan, maka dibutuhkan pencatatan waktu kedua sinyal gelombang tersebut. Perhitungan cepat rambat gelombang permukaan, dapat digunakan persamaan berikut ini:

$$
\begin{aligned}
& v_{R}=\left\{\left(\Delta t_{R} / V_{0} Z\right)-\left(\Delta t_{R}^{2} / 4 Z^{2}\right)\right\}^{-1 / 2} \\
& \Delta t_{R}=t_{i}-t_{R}
\end{aligned}
$$

$$
Z=F-x
$$

$$
x=\frac{\nu_{0} \times t_{i}}{2}
$$

\section{Keterangan:}

$\mathrm{V}_{\mathrm{R}}$ : cepat rambat gelombang permukaan $(\mathrm{m} / \mathrm{s})$ $\mathrm{v}_{\mathrm{o}}$ : cepat rambat di air

$\mathrm{t}_{\mathrm{i}}$ : waktu gelombang utama (s)

$t_{\mathrm{R}}$ : waktu gelombang permukaan (s)

Z: jarak permukaan benda ke fokus probe $(\mathrm{mm})$

$\mathrm{x}$ (=EO'): jarak probe ke permukaan benda $(\mathrm{mm})$

F: Jarak focus

$\mathrm{t}_{\mathrm{i}}$ merupakan waktu datangnya gelombang utama dan $t_{R}$ merupakan waktu datangnya gelombang permukaan sebagaimana diperlihatkan pada Gambar 3, dimana gambar ini memperlihatkan contoh sinyal hasil pengujian dengan metode defocused.

\section{B. Metode Satu Probe}

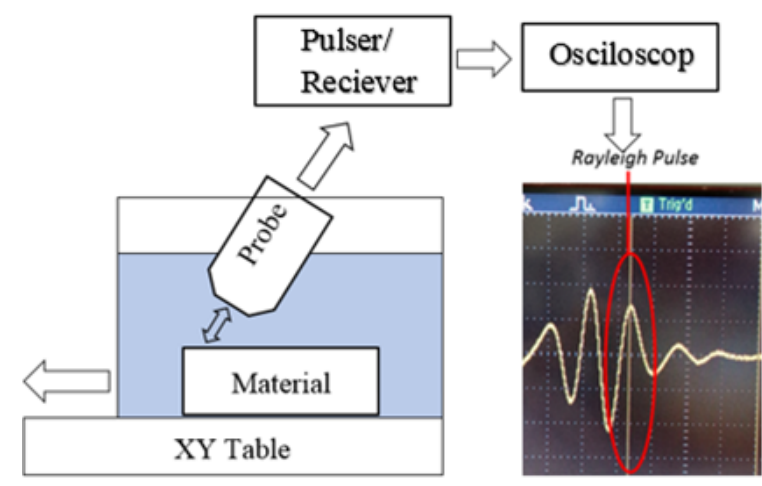

Gambar 5. Skema uji metode satu probe 
Gambar 5 memperlihatkan skema uji metode satu probe. Pada metode ini, sistem pengujian terdiri dari Ultrasonic Pulser Receiver, satu unit Probe dan Oscilloscope. Probe yang digunakan memiliki frekuensi $10 \mathrm{MHz}$ dan tipe fokus dengan jarak fokus 25,4 mm. Pada sistem pengujian ini, gelombang ultrasonik dipancarkan dari probe, setelah mengenai permukaan spesimen akan terjadi gelombang permukaan Rayleigh. Gelombang ini merambat di permukaan spesimen menuju tepi spesimen dan akan dipantulkan pada tepi specimen. Energi gelombang pantul yang bocor ke media air akan diterima kembali oleh probe yang sama. Cepat rambat gelombang permukaan Rayleigh dihitung dengan persamaan berikut ini:

$\mathrm{V}_{\mathrm{R}}=2 \Delta \mathrm{x}_{\mathrm{n}} / \Delta \mathrm{t}_{\mathrm{n}}$

$\Delta \mathrm{x}_{\mathrm{n}}=\mathrm{x}_{\mathrm{n}}-\mathrm{x}_{0}$

$\Delta \mathrm{t}_{\mathrm{n}}=\mathrm{t}_{\mathrm{n}}-\mathrm{t}_{0}$

Keterangan:

$\mathrm{V}_{\mathrm{R}}$ : Cepat rambat gelombang permukaan

$\mathrm{x}_{\mathrm{n}}$ : jarak perpindahan benda uji (mm)

$\mathrm{x}_{0}$ : jarak awal benda uji (mm)

$\mathrm{t}_{\mathrm{n}}$ : waktu datangnya gelombang pada posisi $\mathrm{x}_{\mathrm{n}}$ $\mathrm{t}_{0}$ : waktu datangnya gelombang pada posisi $\mathrm{x}_{0}$

\section{HASIL DAN PEMBAHASAN}

Gambar 6 memperlihatkan hasil penentuan cepat rambat gelombang Rayleigh terhadap variasi jarak perambatan. Jarak perambatan merupakan jarak segmen BC pada Gambar 4. Cepat rambat gelombang ditentukan berdasarkan persamaan (2). Grafik ini memuat grafik dari spesimen non-nitridasi, dan specimen de- ngan nitridasi dengan ketebalan masingmasing 59, 102, dan $160 \mathrm{~mm}$. Dari grafik ini dapat dilihat bahwa cepat rambat gelombang Rayleigh pada setiap benda uji dengan ketebalan lapisan hasil nitridasi yang berbeda memiliki perbedaan yang kecil dan cenderung hampir sama nilainya. Selain itu, nilai cepat rambat juga menunjukkan variasi berdasarkan jarak rambatnya, sementara hal ini seharusnya konstan.

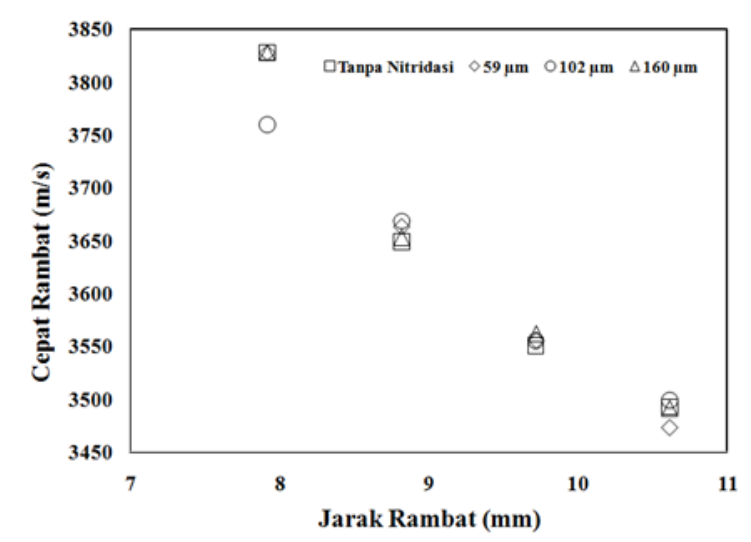

Gambar 6. Hasil pengukuran cepat rambat gelombang Rayleigh dalam variasi jarak rambat dengan metode defocused

Gambar 7 memperlihatkan hasil penentuan cepat rambat gelombang Rayleigh terhadap variasi jarak perambatan. Jarak perambatan adalah jarak antara titik masuk gelombang ultrasonik ke dalam spesimen sampai dengan tepi spesimen. Dari grafik dapat diketahui bahwa pada jarak $1 \mathrm{~mm}$ s.d. $3 \mathrm{~mm}$, cepat rambat gelombang mengalami penurunan, namun setelah itu cenderung pada nilai konstan. Perbedaan ini diakibatkan adanya perbedaan ketelitian pembacaan pulsa. Pada jarak dekat, pulsa gelombang Rayleigh yang terjadi akibat pembiasan dan gelombang Rayleigh pantul jaraknya sangat dekat sehing- 
ga kedua gelombang berhimpitan. Kondisi ini mengakibatkan jarak kedua gelombang sulit ditentukan. Sementara itu, ketika jarak di atas 3 $\mathrm{mm}$, jarak kedua gelombang jelas sehingga penentuan jarak gelombang mudah dilakukan.

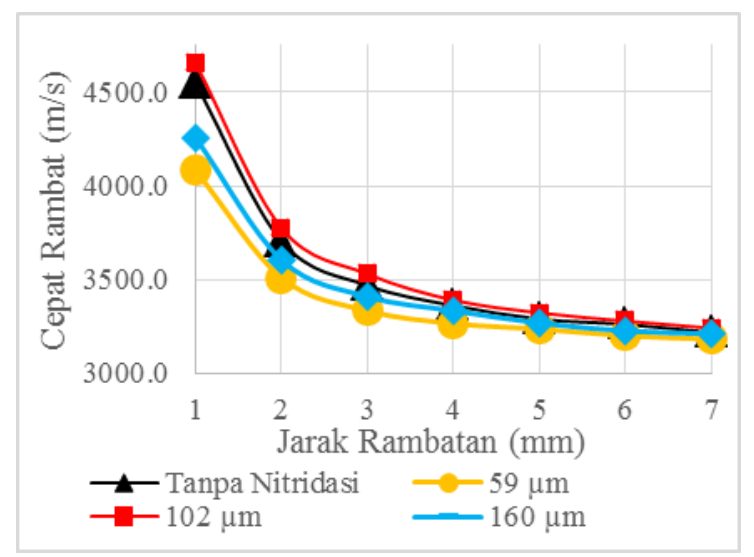

Gambar 7 Hasil pengukuran cepat rambat gelombang Rayleigh dalam variasi jarak rambat dengan metode satu probe

Nilai cepat rambat gelombang memiliki perbedaan, baik pada kondisi tanpa nitridasi maupun perbedaan ketebalan lapisan nitridasi. Namun, perubahan ini tidak memiliki hubungan yang konsisten antara ketebalan lapisan nitridasi dengan cepat rambat gelombang Rayleigh. Karena ketebalan lapisan nitridasi ini berada pada spesimen yang berbeda-beda, sehingga perbedaan ini bukan disebabkan oleh ketebalan lapisan nitridasi.

Berdasarkan dari sifat perambatan gelombang Rayleigh, adanya ketebalan lapisan nitridasi akan mempengaruhi gelombang Rayleigh. Tabel 2 memper-lihatkan hasil pengujian kekerasan pada semua jenis spesimen. Dari table ini dapat diketahui bahwa masing-masing spesimen memiliki kekerasan yang berbedabeda, dimana spesimen tanpa nitridasi memliki kekerasan yang paling rendah, sedangkan lapi- san nitridasi dengan ketebalan yang paling besar memiliki nilai kekerasan yang paling tinggi. Berdasarkan sifatnya, keberadaan lapisan nitridasi akan meningkatkan nilai cepat rambat gelombang Rayleigh.

Tabel 2. Hasil Pengujian Kekerasan Mikro

\begin{tabular}{|l|c|c|c|}
\hline \multicolumn{4}{|c|}{ Nilai Kekerasan (HV) } \\
\hline $\begin{array}{l}\text { Tanpa } \\
\text { nitridasi }\end{array}$ & $59 \mu \mathrm{m}$ & $102 \mu \mathrm{m}$ & $160 \mu \mathrm{m}$ \\
\hline 290,8 & 1104,1 & 1391,3 & 1566,6 \\
\hline
\end{tabular}

Pada pengujian dengan frekuensi sebesar $10 \mathrm{MHz}$ ini, apabila dihitung panjang gelombangnya, maka panjang gelombang yang dihasilkan $359 \mu \mathrm{m}$. Sementara itu, ketebalan lapisan nitridasi pada benda uji yang digunakan adalah $59 \mu \mathrm{m}, 102 \mu \mathrm{m}$, dan 160 $\mu \mathrm{m}$. Jika dilihat dari rasio antara kedalaman lapisan nitridasi dengan panjang gelombang dari gelombang yang digunakan $(\mathrm{z} / \lambda \mathrm{R})$, pada ketebalan nitridasi $59 \mu \mathrm{m}$ bernilai 0,16 , pada ketebalan $102 \mu \mathrm{m}$ bernilai 0,28 , dan pada ketebalan $160 \mu \mathrm{m}$ bernilai 0,44 . Jika dilihat dari angka tersebut, kemungkinan besar ketebalan $102 \mu \mathrm{m}$ dan $160 \mu \mathrm{m}$ yang dapat dideteksi oleh gelombang permukaan (mengacu pada distribusi intensitas energi gelombang Rayleigh pada Gambar 1. Ketidakmampuan sistem pengujian ini dalam mendeteksi perubahan cepat rambat gelombang Rayleigh dapat dijelaskan melalui Gambar 8 . Gambar 8 memperlihatkan sinyal hasil pengujian dengan metode defocused. Dari gambar ini jelas terlihat bahwa sinyal gelombang Rayleigh sangat kecil apabila dibandingkan dengan sinyal gelombang utama yang tegak lurus terhadap probe. 


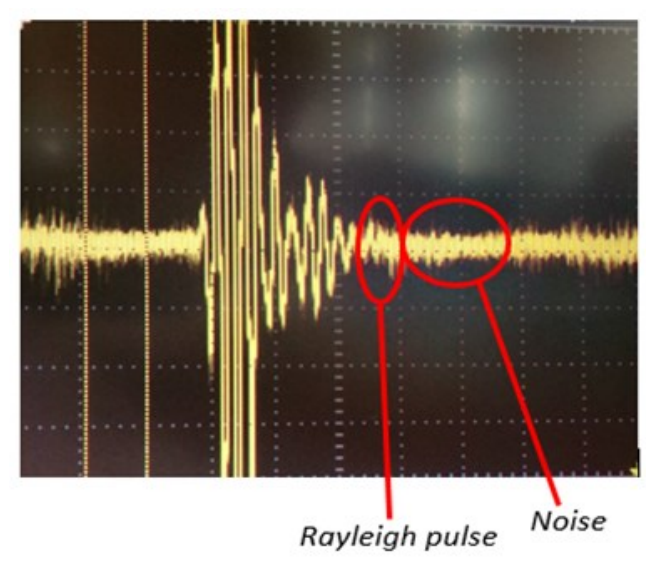

Gambar 8. Gelombang Permukaan Yang Terganggu Gelombang Noise

Secara teoritis, memang gelombang ini memiliki intensitas yang kecil, karena sinyal yang ditangkap oleh probe ini bukan sinyal yang langsung diterima oleh probe, melainkan sinyal bocor. Sehingga, karena sinyalnya kecil dan nilainya hampir sama dengan noise, sehingga sangat sulit dalam menentukan kapan waktu datang sinyal yang sebenarnya. Jadi, secara sistem diperlukan alat yang memiliki SNR (signal to noise ratio) yang baik, sehingga dapat membedakan dengan jelas antara sinyal lemah dengan noise.

\section{KESIMPULAN}

Telah dilakukan pengukuran ketebalan lapisan nitridasi menggunakan metode ultrasonik dengan gelombang permukaan Rayleigh. Pengukuran dilakukan dengan metode satu probe dan metode defocused. Hasil pengukuran menunjukkan bahwa, metode defocused tidak memperlihatkan pengaruh ketebalan lapisan nitridasi pada cepat rambat gelombang Rayleigh, sementara metode satu probe memperlihatkan pengaruh ketebalan lapisan nitridasi terhadap cepat rambat gelombang Rayleigh.
Dari hasil pengukuran dengan sistem ini menunjukkan bahwa metode satu probe lebih unggul dari metode defocused. Untuk meningkatkan sistem pengukuran ini diperlukan peningkatan signal to noise ratio, guna dapat membedakan dengan jelas antara gelombang Rayleigh yang memiliki energi sangat kecil dengan noise.

\section{UCAPAN TERIMA KASIH}

Penulis menyampaikan terima kasih kepada Pusat Teknologi dan Keselamatan Reaktor Nuklir yang telah member fasilitas pengujian sehingga terlaksananya penelitian ini. Ucapan terima kasih penulis sampaikan juga kepada para staf Bidang Pengembangan Fasilitas Keselamatan Reaktor-PTKRNBATAN, yang telah membimbing operasional alat.

\section{DAFTAR PUSTAKA}

1. R. Himawan, H. Katoh, Cahyono, Atom 36, 63-68 (2010).

2. M. Fauzi, R. Himawan, H. F. Rahmatullah, S. Permana, Urania 23, 153-164 (2017).

3. H. M. Shodja, A. Ghafarollahi, C. Enzevaee, International Journal of Solids and Structures. 108, 63-73 (2017).

4. Y. Shen, S. Hirose, Y. Yamaguchi, Case Studies in Nondestructive Testing and Evaluation 2, 49-63 (2014).

5. H. Goto, N. Tanaka, S. Sawada, H. Inatani, Soils Found. 55, 1282-1292 (2015). 
6. M. Henriquez, A. J. H. M. Reniers, B. G. Ruessink, M. J. F. Stive, Coast. Eng. 94, 33-46 (2014).

7. A. Stips, H. Burchard, K. Bolding, H. Prandke, A. Simone, A. Wüest, Deep Sea Res. Part II Topical Studies Oceanography 52, 1133-1155 (2005).

8. M. Teymur, A. Demirci, S. Ahmetolan, International Journal of Engineering Science 85, 150-162 (2014).

9. E. Hu, Y. He, Y. Chen, Applied Acoustics 70, 356-360 (2009).

10. C. I. Lin, Y. Lu, C. He, G. Song, Y.C. Lee, NDT \& E International 74, 43-49 (2015).

11. I.A. Viktorov, Rayleigh and Lamb Waves Physical Theory and Applications, Collumbia University, 1967.

12. R. I. Zuhrial, T. Bernhard, T. R. Ramalis, Fibusi (JoF) 3, (2015).

13. K. Yamanaka, Journal of Applied Physics 54, 4323-4329 (1983). 